\title{
POETIC SIDE OF A TRAVELOGUE THROUGH THE „ACCORD OF DIFFERENT WORLDS“
}

\author{
Nina Alihodžić-Hadžialić
}

\begin{abstract}
The subject dealt with in this work is non-hegemonic discourse which, in the spectre of philological interests, denounces the phenomena of hierarchialisation and dehierarchialisation linked to the problem of capturing the concept of the function a border has while being disseminated through literary theory and practice throughout travelogue as a literary form. By enquiring about cultural heritage applied in literature from Odyssey's travels and challenges, this research has attempted to emphatically "listen poetically" to all aspects of human existence subjected by some to the border line of such worlds. Thus I here write about an exemplary travelogue which uses conceptual mechanism of its text based on the movement disputing then a conventional usage of literary language, which is today recognized as a form of violence as old as the very western history itself is. For that purpose, the work has incorporated analytical viewing of novelistic, essayistic and travelogue like literary heritage using travelogue essays Majka voda by Tvrtko Kulenovic, the most famous Bosnian-Herzegovinian writer and essayist. It is a travelogue of great significance taking us from "postmodern Odyssey" to its specific "ideology of water" and "religion of seas". The ephemeral border between a body travelling to a body of travelling in his travelogue Majka voda takes us to the point of merging of two cultural circles. Poetic dimension may be inferred from Kulenovic's suggestions: "Indeed, is there any shame in the fact that it is more intelligent to sail rather than row (...) That artistic skill is obtained more easily through the "eastern" relaxed surrender then
\end{abstract}


through the "western" intent and concentration (attempt to forcibly control mind equals the attempt to even out the waves of the sea). Who hits the target, misses all? (...) We must be capable of changing our shape as water does. (...) In the beginning there was no word, but water. At least it is said so in the Book of Genesis: the holy spirit of God soared above the waters." (Kulenovic: Majka voda)

Keywords: Deconstruction, Iterology, Myth, Post-colonialism, Post-modernism, Travelogue 
Quite to the contrary, they thought they would be lured out to some dangerous southward island, through senses of their world and through cold realm of "ideas", where even their philosophic virtues would melt, they were afraid, as the snow melted by the sun. "The wax in ears"method then was almost a precondition for philosophizing; a real philosopher did not listen to the life anymore; if the life was music, he denied the music of life... The ice still holds but it has drastically thinned down; the Southern wind blows, we are alone and homelandless, something that cracks the ice and makes the "realities" too thin...

Friedrich Nietzsche

The Gay Science

A travelogue is the place where a literary theoretician may be a picaresque hero without any fear.

Tvrtko Kulenović

\section{INTRODUCTION}

In modern literature, whether regarding subversive works of modernism or postmodernism literature, as well as post-colonial literature, it is noticeable that all those artistic artefacts contain a special „organizational“ solution of narration construction aiming at open criticism of social and cultural conceptions of the Western civilization. Speaking of problems of policy and ethics of narration in the postcolonial literature-critical attitude means, inter alia, pointing at the possibility of genre, not only as the indicator of changes of dominant world picture, but also as the discursive field where deconstruction of genre scope becomes the generator of changes. In that sense, we can hardly accept the postulate that the motional dynamics in literature, fully destabilizing a dichotomy conceptual scheme, can realize the out-genre hybrid literature productions.

Examining the cultural literary heritage used through Odysseus's wanderings and temptations, we stop our attempt to "poetically listen“ to the aspects of existence handing over a human being to the edges of marginal worlds. Therefore, I speak about the literary examples in 
which a conceptual mechanism rests in the Movement, thus denying the conventional usage of literary language, hence, the representative usage recognized by us nowadays as the sort of violence as old as the Western history itself. The connotations leading through tran-historical discussion on science and literature refer to the articulation of relations between the literature and the culture of travelling. As for the mentioned issue, being as suggestive one, I can recognize the fragment of Dean Dude's book titled The Culture of Travelling: An Introduction to Literary Iterology, making me select the following idea: „Did the reconstruction processes in civil society in the post socialist context just repeat the sequence typical for capitalist literary-market articulation of the long 19th century or it is a somewhat more complex rhythm of literary evolution? (Duda 2012: 220)

\section{ODYSSEUS AND ENLIGHTENMENT}

In the relation to this, I'd recall the excurse titled Odysseus, or myth and enlightenment added by Max Horkheimer and Theodor Adorno in their book named Dialectics of Enlightenment. Their attitude is based on the assertion that a Homeric text is the basic text of European civilWestern civilization and as such it became a civilization epopee and that, "the sly individual, de facto, the homo oeconomicus resembling all the lucid ones" is Odysseus as the prototype of a castaway whose way to success is interpreted as the pre-principles that constituted civil mind.

Comparing Odysseus to Robinson, Horkheimer and Adorno diagnosed radical estrangement through the phenomenon of totality and hostile attitude towards all the ,intruders" threatening to the mind of selfpreservation as „the happiness at the edges of the world“. In this sense, The Odyssey clearly emphasizes „the demons who cast a spell“, the temptations shown as a kind of oriental pleasure in several Odysseus's adventures. By this way, mythical monsters whose territories Odysseus dared to visit converted his journey into a wandering, complying, at some moments, with demands dating from pre-historical times. Episodes where he met weaknesses of rational view over the space of self-consciousness, the 
moments when he failed to trust in his knowledge and freely left himself to the wizard to intoxicate his senses, are all the symptoms of expropriation of „the power of path“ of his logic.

It is possible to use the searching method of two models of journey to speak about steady peace of Homeric world in the sense of recognition of civil-enlightening prototype of rational order through the spectacle onto the history of value systems. On one hand, we are the witnesses of "traditional model of journey", its range and projects, while, on the other side of experience, we can perceive

journeys causing certain transformations of selfhood. In this sense, Dean Duda writes: „in Odysseus's case it is not just a bare fact of outcome of a toilsome absence“. (Duda 2012: 53)

Duda particularly accented comparative search in the comprehensive study devoted to the culture of travel sling, where he investigated the possibility of literariness in travel literature, searching for the spots of resistance in the literary production resulting in „a dominant moment of transformation of a person caused by the act of travelling". The attitude connoting the ethics of postcolonial space of endless and tactless liminality „relieves" the conception of clear demarcations in literary theory. As for this, the Greek world and antique philosophy, as the heritage of great philosophers, rest in the ideas of uniformity and non-contradiction, however, the mentioned ideas are, at the same time, "measurable" only in the experience of their contrasts. Following the example of opinion, in the context of postcolonial justification, it is clearly necessary to examine the existence of the myth on Odysseus in the construction of the world we have been living in, and to examine the fact that the myth comprised in the epic poem as its "backbone“, in fact, "perfectly“ fits in the scientific philosophy of logical positivism. Regarding the mentioned theme, Duda notes the following:

It regards much more than the return itself: almost a ritual confirmation setting all things back to the right place. Odysseus's ten-year wandering, as arduous narrative imbalance and longlasting temporariness, does not finish only by spatial return to 
Ithaca, but it develops as a (ritual) solvation of all problems caused by his absence. This enables him to confirm all his roles assumed by patriarchal imagination: Odysseus has approved himself as a son, a father, a husband and a ruler, establishing, in this way, a certain landmark of values, semantics of long-lasting "return" in the history of (patriarchal) conception of the Western literature.

(Duda 2012: 53)

\subsection{Poetic spot in the Odyssey}

Nevertheless, there is a certain misbalance at „furnished“ surface of Homeric style that opened the place of border throughout the poetic language of thoughts. Although Homer "pushed“ obligatory wax into his sailors' ears, Odysseus suffered the pain of "allure of moments themselves", hence he is atypical hero compared to those from classic myths. His adventures, captivity by fairies, meeting with mermaids, show many switching points available during the journey deprived of Apollonic anaesthetic instruments. Facing the pulsing vividness of physical emotional frame, Odysseus enters the "forbidden country" of individuality. Hence, Odysseus's individuality develops from the painful polysemic mobility of narration where a "crack “ is open in silent epic space. By adverse distinguished activity of Apollonian and Dionysian side shown in „sensuous" as a symptom, Homer's Odyssey hinted the "playful world of carnival society“ striving to endless dialogue. As for this, I suggest the syntax of regent values of historical genre poetry i.e. travelogue should be extended to the theoretically recovered spots treated contrary to "the old philosophic superstition belief that every music is music of mermaids“.

The affirmative understanding of shifting of the term "tourist" by the term "traveller", would be directed to the idea that there is a real possibility to speak out using the „creativity of marginal reasoning“.

According to the notices of Jorge Luis Borges in the book titled "The art of verse", the books are just favourable chance for poetry" and the life, according to him, is "made of poetry“. 
...There is something in narration, in story, that will survive. I don't think the people will ever get tired of narrating the stories or of listening to them. If we get additional joy of verse dignity beside the joy of narration itself, then something big is going to happen. (Borges 2001: 50)

The challenge offered by Borges to the literary theoretical as well as artistic practice of writing also incorporates analysis of literariness of travel literature. Dislocation of genre margins being the chance for meeting with the spots of resistance surely absorbs certain dislocation of conceptually clearly defined knowledge categories on geographical map, in the sense of meeting of two cultural circles. As for this, subversive practice is obvious and typical of postcolonial sentiment, as orientation toward the Other and affirmation of exotic, miracle otherness. The examples are Odysseus's wanderings over the edges of the world known to him, taking him to the farthest spots of realizable world; to mythical conceptions and irrational experiences where the possibility of magical transformation of selfness may be realized.

\section{LIRISM IN TRAVELOGUE}

The book named Majka Voda (Mother Water), the collection of travel essays written by Bosnian-Herzegovinian writer Tvrtko Kulenović is the extraordinary example of travel literature where conceptual text mechanism rests on the movement through sensual senses of experienced journey. It is the travelogue covered by inspired lyrism of literary artistic narration of a "postmodern nomad" in the open form of rhizomatic itinerary.

However, the analysis of poetical dimension in the travel literature was accented by Kulenović in the travelogue written many years before the mentioned anthology. In his travelogue titled The Journey, the writer analysed practice of writing from the perspective of possibility of opening of the travelogue genre toward special sensibility that would become the principle of the text organization in the way to be moved away from conventional usage of linguistic phrase recognized as severely representative usage. 
Just like a "postmodern Odysseus" searching for the "porous borders" of experience and knowledge, Kulenović searches for possibility to write out the "grammatical form circle" of traditional practice of travel literature that he recognizes as a sort of hegemonic discourse. Foreboding the importance of transformation brought by the journey itself, where a traveling body should transform into liminality of the traveling body, Kulenović wrote:

I claimed that the real job of a travelogue writer is not to be occupied by certain landscapes and places but to search for the process of traveling itself, the way we change the places and the way those places change us. Within the scope defined by his literary genre and material he uses, a travel writer is obliged to step out into other human fields and problems that other genres are also facing with; and it is very difficult especially in two cases: when the described places and towns are very close and familiar, and when they are very far and unknown. In the first case the travel writer will be dragged down by the novel not only requiring different and huge literary skill but also narrates its mandatory fabrication, a lie; in the second case he will be dragged down by a reportage hiding the misery of its procédé behind trivial reality of its themes. I was warning myself about the latter danger that might cause very serious consequences when it regards India. (Kulenović 1974: 77-78)

In the paragraph above, I can recognize the writer feeling the lyric sort of revolt against the "literature of completeness" making the readers become almost "paralyzed by other's words in them“. By virtuality of a lyric subject, Kulenović listens to the voice of otherness in himself exploring cosmic widths of selfness, in order to reach the sontological dimension of "eternal traveller" through the form of travelogue. During the process, high level of entangledness of the moment of pursuit is emphasized as a two-way corridor - from himself to others and from others to him. In this sense, the text deconstruction in the phase of writing regards also the search for himself as for the subject taking himself to existence while writing and traveling. Auto-referential dimension of Kulenović's travelogues deconstructs travelogue notation, by the genre, through the writer's attempt to cross the border of phallogocentrism heading toward 
genuine communication „on the other side of Knowledge and Words“.

Reviewing the mentioned essays of Horkheimer and Adorno on Odysseus where they conclude that "Wandering from Troy to Ithaca is traveling of physically fragile selfness (Horkheimer-Adorno 1974: 60), in Kulenovićs writings I can recognize the endless literary coloration, from mythic to present one. Anthropologic dimension of "eternal return" is recalled by the writer through "mythic mother's body“ where, at the same time, two basic principles co-exist, both artistic but also regular, daily ones. The connoting dimensions of Eros and Thanatos in "short circuit", Kulenović takes the readers over the text margins, in the spirit of postmodernism.

And I can feel that the temple on the seaside is just a symbol, just a channel as the shortest way for the flow of primeval longing to erupt through, the longing older than longing for warmth of mother's intestine, ancient longing of ours for dark depth of water.

The question nagging humans from their genesis, the question about connection between the birth and the death, is here simply answered: (...) the death is re-immersing into the dark depth of water we originated from, followed by a shimmer gradually disappearing. (Kulenović 2004: 260)

Moving the borders of static categories of genre scopes originated from pseudo-enlightening beliefs, in his book named Majka voda (Mother Water), Kulenović introduced dynamic and fluid philosophy of commitment to „ideology of water" and „religion of sea“.

Sea - restless field, as said by an adage. It teaches us of beauty of movement. During the years of traveling, the sea becomes the homeland of travellers. (...) It takes over the most beautiful cities, knowing that the cities represent most of excitement to a real traveller, the cities are concentration within the flesh of journey (...) that real moving exists only at the sea, because only arrivals exist at the land; the land is only for false and weak travellers (...) But the sea, strange and unknown, the sea that will remain strange even when it becomes, the space best fitting to the time forever extraneous and coming after death. (...) Hoisting the life, the sea 
fights against the people's attempt to make it a habit: it suddenly cuts its sequences of stillness by intrusion of storms, knowing that the fear is the best disillusion remedy against dull insobriety of duration, drawing out, from the bottom of its intestine, always unknown and new beings do confronting them against security and comfort of our definitions and classifications. Hence it has right to proclaim itself a centre of religion, object of warship; it consoles us by its testimony on the existence of other worlds. (Kulenović 2004: 46 - 48)

Encountering two cultural scopes, East and West, Kulenović also contoured poetic dimension of travelogue. Writing about meetings with the farthest Other Ones, he speaks about his experiences of "the accord of the worlds". Noting his journeys throughout cities on water from Mediterranean to the Far East, Kulenović senses, through epistemological challenges and poet's subtlety, an ontological dimension where the „mythology of sailing“ shows up as the law of existence.

In case that the "ideology of water" reminds us too much of everything we are usually inclined to attribute to the East, while we „blemish the East etiquetting it with passivism, quietism, resignation, lack of firmness and combativeness", let's not forget "what the hardest object is?": a rubber water pipe. The water does not move downwards only. If the Wu Wei principle unnerves us as the "advisory principle", let us remember that its basis is Li as ontological principle, the law on existence, and the law on existence is the law on movement, its best reflection is in the water. Li is surely an order, organization, not on the form of military order but asymmetrical, non-repetitive order we find in the shape of running water. Dancing flexuosity of the nature. Li is the principle of order and the water is its most eloquent metaphor.

Indeed, what is shameful in consideration that sailing is more intelligent than paddling? (...) This skill is easier obtained through "Eastern" relaxation and commitment rather than through the "Western" intention and concentration (attempts of forced control of mind are equal to attempts of levelling of water surface by a board. "He who hits the target misses the rest of it", the poet wrote. He who watches right and only in front of himself, can't see the things coming by his side... (Kulenović 2004: 204-205) 


\section{CONCLUSION}

Affirmation of "the culture of traveling" both literally but as well as in its metaphoric elongation, is realized through the culture of consideration on cracking of static Cartesian cogito in the name of embodiment of so-called "nomad subject“. Dimension of „settlement" as basic principle of human estrangement is described by Kulenović as a contrast to motive power of „mechanics of fluids“.

We must be able to change our shape as the water does. Because, when we are caught and captured in the prison, we can get out through the smallest crack in the wall if we manage to become like water. A solid element may be taken out of the hole only in case it is smaller than the hole itself. China has tried to find freedom for humans in what we consider human jeopardy. It is named Tao, a path, a water path, a constantly changing rug beneath our legs, moving, passing, flowing, disappearing, because the path that can be named is not Tao. (...) Both the water and the Tao, should be understood the way the poetry is understood, trying also to comprise all while ,showing the life" (...) The greatest wisdom and the most distinctive message from the East is contained in such larpurlartism of life, in human's comprehension and imitation of such simple mechanics of fluids (Kulenović 2004: 205 - 206; 217)

And finally, at the spots of "poetic attack of theoretical mind“ in the mentioned considerations on travel literature, I'd confirm Michel Butor's old idea on methodology of literary scientific discipline decentralized by "poetic approach". This makes me see the iterology as a marginal discipline, „a cheerful science“ on processes of permutation and transformation, dislocation and transfer, in communication and hermeneutic meeting of postmodern reading of intellectual history through common slogan: Cross the Border - Close the Gap (Leslie Fielder 1972).

I'd renounce my final idea in favour of the writer who shows, by his excellent travelogue, the possibility for this literary genre to be the place of "literary evolution“, if there are lyric dimensions of piety towards magical world of literature and relation to the life in general. 
In the beginning, there wasn't word but water. At least, it is written in the Book of Genesis: the spirit of God was floating over the waters. The relation between the Spirit and the water is primer relationship of God and material world.

The water occupies the lowest places, it embraces what people despise, and it accepts all shapes and reflects the sky. It does not fight for any permanent form or position. Eternal goodness is like water useful to all beings. The best of humans is similar to water. If the life is the river, be a boat, a tree broken off and flown away by the water, but the tree floating through that river with beautifully outspread limbs - wings. (Kulenović 2004: 202, 203) 


\section{REFERENCES}

Auerbach, E. 1979. Mimesis. Prikazivanje stvarnosti u zapadnoj stvarnosti $\mathrm{U}$ : Moderna teorija romana (Interpretation of reality in Western reality in: Modern Theory of Novel ). ur.Solar Milivoj. Beograd: Nolit.

Baudrillard, J. 1991. Simbolička razmena i smrt. (Symbolic Exchange and Death). Gornji Milanovac: Dečje novine.

Borges, J. L. 2001. To umijeće stiha (That Artistry of a Verse). Zagreb : Naklada Jesenski i Turk.

Compagnon A. 2001. Demon teorije (Demon of Theory). Novi Sad: Svetovi.

Duda, D. 2012. Kultura putovanja. Uvod u knjževnu iterologiju (Culture of Traveling. Introduction to literary iterology). Zagreb: Naklada Ljevak.

Horkheimer, M. - Adorno, T. 1974. Dijalektika prosvjetiteljstva (Dialectics of Enlightenment). Sarajevo: Veselin Masleša.

Kulenović, T. 1974. Putovanje. (Journey). Sarajevo: Svjetlost IP.

Kulenović, T. 2004. Majka voda (Mother Water). Sarajevo: OKO.

Norris C. 1990. Dekonstrukcija: kraj metafizike i novo mišljenje od Ničea do Derride (Deconstruction: end of metaphysics and new attitude from Nietzsche to Derrida. Beograd: Nolit.

Ricoeur P. 2004. Sopstvo kao drugi (Selfness as Otherness). Beograd: Jasen. 
